\title{
СУЧАСНА УКРАЇНСЬКА ФОЛЬКЛОРИСТИКА: МЕТОДИ І ФОРМИ МИСТЕЦЬКОЇ ДІЯЛЬНОСТІ (ПРАКТИЧНИЙ АСПЕКТ)
}

\author{
Сінельнікова В. В., Сінельніков І. Г.
}

\section{ВСТУП}

Зацікавленість сучасного українського суспільства фольклорною тематикою та популярність народно-пісенних колективів, репертуар яких безпосередньо пов'язаний із музичною фольклорною традицією, що постійно збільшується, обумовлені високохудожньою естетичною природою традиційного народного мистецтва, що $\epsilon$ сьогодні надзвичайно затребуваним у зв'язку із сучасними соціальнокультурними реаліями та завданнями відродження України, а саме іiі економіки, культури, освіти, духовної сфери. В цьому контексті надзвичайно актуалізується роль молодіжних фольклористичних формацій і так званого молодіжного фольклорного руху, в основі діяльності якого лежать польова фольклористично-дослідницька діяльність та музично-теоретичне й практичне опрацювання експедиційного матеріалу.

Відродження традиційної пісенної культури та роль у цьому процесі молодіжних репродукуючих («вторинних», «секундарних», науковоетнографічних) ансамблів $\epsilon$ одними 3 найактуальніших проблем сучасної практичної музичної фольклористики, де питання історії, теорії і методики творчого засвоєння народного пісенного мистецтва являють собою живий процес відтворення регіональних пісенних традицій, народної співацької «школи», музичного фольклору загалом. Цим обумовлено створення «вторинних» («імітаторських») фольклорних колективів, головним завданням яких $є$ автентичне (або наближене до автентичного) відтворення зразків музичного фольклору, реконструкція пісенної традиції в різноманітній та багатогранній концертно-виконавській сценічній практиці з урахуванням сучасного культурно-мистецького життя й глибокого вивчення пісенних традицій.

Осягнення «етнічного звуку», занурення у близьке до автентичного звучання музичного фольклору є необхідним як науковий i творчий експеримент у пошуку виконавських прийомів, спрямованих на 
збереження та популяризацію «еталонного» звучання народної пісні ${ }^{1}$. Сьогодні фольклорний спів зацікавлює не лише як репертуарний ресурс або засіб виховання естетичного смаку, але й як спосіб світосприйняття та пізнання людиною самої себе, адже весь моральноетичний комплекс поглядів українського народу закладений в українському музичному фольклорі, тому учасники молодіжних фольклорних колективів $є$ цікавими i незвичними для сучасного суспільства. Вони приходять у колектив не просто «поспівати». Кожний 3 них $є$ особистістю, що бажає пізнання самої себе, національного коріння, культури свого народу. Для учасників фольклористичного руху участь у ньому $\epsilon$ не простим видом діяльності, а певним «служінням» традиційній культурі, заснованим на синтезі іiі «інтуїтивного, духовного й наукового пізнання 〈..> як цілісної системи» ${ }^{2}$. Це обумовлює формування та розвиток таких способів «життєдіяльності» сучасних фольклористичних формацій, як «спільна рефлексія, активний обмін досвідом, знаннями на творчих майстернях, у живій формі; проведення концертів, як можливість просвітницької роботи у суспільстві» ${ }^{3}$. Завдяки зусиллям молодих фольклористів, співаків не відбувається забуття фольклорної пісні, відновлюється інтерес до «старого», «справжнього», «первинного».

Розглянемо детальніше методи та форми мистецької діяльності сучасних українських вторинних (секундарних, експериментальних) молодіжних фольклористичних формацій.

\section{1. Музично-експедиційна діяльність сучасних молодіжних фольклористичних формацій України}

Історія розвитку фольклорного руху у молодіжному середовищі та його впливу на формування особистості пов'язана 3 ім'ям Дмитра Покровського, діяльність його колективу цілком може бути прикладом яскравої реакції суспільства та значного резонансу його творчої діяльності на багато років. Коли в середині 1970-х років на сцену «увірвався» Дмитро Покровський зі своїм ансамблем, почався справжній «фольклорний бум»: на теренах тодішнього СРСР з'явилися послідовники й соратники Д. Покровського, як, наприклад, у 1979-му

1 Сінельнікова В., Сінельніков I. Деякі питання засвоєння автентичної традиції співу у міському молодіжному фольклористичному колективі. Імідж сучасного педагога. 2019. № 4 (187). С. 94-99. URL: http://isp.poippo.pl.ua/article/view/168463/178248 (дата звернення: 28.01.2021).

2 Андреева Е. Фольклорное движение как культурный феномен второй половины XX столетия. История и современность. 2013. Вып. 2 (18). URL: https://www.socionauki.ru/journal/articles/159684 (дата звернення: 02.02.2021).

${ }^{3}$ Там само. 
році Євген Єфремов та фольклорний гурт «Древо» Київської консерваторії (сьогодні - Національна музична академія України ім. П. Чайковського).

Як на початку фольклорного руху, так i сьогодні творчість фольклористичних колективів викликає найрізноманітнішу реакцію у суспільстві: від захоплення до різкого несприйняття і навіть відрази. Однак піонери цього руху дійсно сколихнули усю країну, «приспану» тоді «псевдозадушевним» ${ }^{4}$ звучанням народних хорів. Д. Покровський і його послідовники запропонували зовсім новий - не «лубочний» i не «шараварний» - незвичайно динамічний і дуже сучасний образ фольклору, у якому фольклорна пісня мала сміливе новаторство, активний особистісний прояв, що перетворювало ії на соціально значуще явище.

В цьому контексті потрібно наголосити на тому, що досі у музичній фольклористиці існує проблема визначення дефініції «фольклорний ансамбль». Як демонструють конкурси дитячих i молодіжних фольклорних ансамблів, багато колективів, що називають себе фольклорними, обмежуються лише одним напрямом діяльності - співом. Спробуємо визначити, який ансамбль може називати себе фольклорним, а також класифікувати колективи, які так чи інакше у своїй творчості використовують фольклорну спадщину українського народу.

Першою групою таких колективів визначимо ансамблі (інколи театри) пісні (пісні й танцю), аматорські (самодіяльні) колективи, що $\epsilon$ наслідувачами справи народних хорів, ансамблів пісні й танцю. Основу репертуару таких формацій складають авторські пісні, якщо фольклор, то безвідносно до будь-якої традиції. Учасники зазвичай вдягнені в однакові костюми 3 аплікацією або у неграмотно стилізовані народні строї, ідея яких залишилася також ще від народних хорів 1970-х років. В складі колективу часто $є$ інструментальна група (або акомпаніатор баяніст), яка (який) бере участь в концертах разом із вокальною групою. Інколи в таких ансамблях народної пісні в репертуарі $\epsilon$ фольклорний матеріал в обробці, хоча на місцевих вокальних або діалектних особливостях тут увага не акцентується, загальний підхід до творчості $є$ близьким до хорового. Під час виконання пісень не береться до уваги їх жанрова приналежність: під танцювальні пісні учасники стоять на місці, і навпаки, під ліричні пісні водять хороводи. Кількісний склад таких колективів може бути різним, в середньому складаючи 20-30 осіб. Для них характерні невідповідність назви й кількості учасників, віку й репертуару, одночасна присутність і навіть

4 Дорохова Е. Молодежные фольклорные ансамбли в городе. Фольклор: проблемы сохранения, изучения $u$ пропаганды. Тезисы Всесоюзной научнопрактической конференции : в 2 ч. Москва, 1988. С. 45-46. 
домінування молодших на фоні старших на імітованих «вечорницях» чи «святах», під час вибудовування яких (так званих сцен із народного життя) завжди використовується поняття «фольклорна картинка».

Друга група - фольклорні сценічні ансамблі, які уважно ставляться до жанрової природи творів, але їх основним амплуа $\epsilon$ зазвичай вокальне мистецтво, використання інших мистецьких форм для них $\epsilon$ рідкістю, хоча співати вони вміють віртуозно. Учасники таких сценічних фольклорних колективів одягаються по-різному, але здебільшого у грамотно стилізовані костюми, які частково шиють самі. В ансамблі часто $є$ кілька вікових груп, що відповідає логіці народної культури. Під час репетицій такі колективи намагаються слухати голоси автентичних виконавців, репетирують і виступають на сцені часто без супроводу. Мінусом у творчий діяльності таких колективів $€$ легковажне ставлення до діалекту, а також те, що вони не прагнуть достовірного відтворення форм традиційної культури.

Третя група - власне фольклорні/фольклористичні ансамблі, що відрізняються від інших вивченням і відтворенням всього 1-2 місцевих локальних традицій, використанням не лише вокалу, але й народних інструментів, часто влаштовують вечорниці та народні свята задля залучення широких кіл населення до народної культури. Саме такі колективи займаються справжнім фольклором, а саме працюють із носіями традицій, достовірно відтворюють форми народної культури, вивчають i засвоюють локальні традиції задля відтворення та збереження різних форм традиційної культури. Такі колективи часто вирізняються невеликим складом: 3-8 осіб; учасники одягаються у відтворені з музейних зразків строї, які шиють самі. Для такого типу ансамблів народна культура не $є$ пустим звуком, адже вони ії вивчають. Учасники таких колективів співають традиційну лірику без супроводу, під інструменти та коломийки (або частівки) танцюють, тобто інструменти звучать там, де слід, і так, як у традиції.

Четверта група (а за вагомістю у збереженні та ретрансляції традиційної культури - перша) - це автентичні фольклорні колективи, які неодноразово були охарактеризовані в науковій літературі. Це носії культури й традицій, що мешкають у тій місцевості (зазвичай сільській), традицію якої вони відтворюють, тобто в репертуарі яких зберігаються локально-регіональні особливості місцевого фольклору. Нині це зазвичай люди похилого віку, колективів таких щороку залишається все менше й менше. 
Спираючись на наукові розвідки наших попередників ${ }^{5}$, розширимо та дещо деталізуємо наведену вище класифікацію фольклористичних колективів. Отже, до першої групи віднесемо аутентичні (етнографічні) фольклорні ансамблі; до другої - вторинні (секундарні) колективи, для яких $є$ характерними відродження та засвоєння жанрів традиційного фольклору (міські молодіжні науково-етнографічні колективи). Їх діяльність може здійснюватися у середовищі, не пов'язаному з народною культурою. Репертуар засвоюється в результаті вивчення народних традицій, безпосередньо в процесі збирацької діяльності. У складі цієї групи виокремимо ансамблі, що репрезентують відновлений (реставрований) фольклор за архівними матеріалами й записами.

Третя група - так звані стилізаторські (сценічні) фольклорні ансамблі, репертуар яких заснований на обробках фольклору. Для них $є$ характерними переосмислення художніх прототипів і традицій, орієнтація на створення умовно-традиційних, узагальнених, загальнонаціональних форм. Четверта группа - ансамблі етнофутуристичного спрямування (етно-рок, етно-поп, етно-джаз, етно-хаос, електро-фолк, фолк-фанк, фолк-панк, фолк-метал, неофолк, прогресив-фолк, альтернативний фолк, антіфолк тощо).

Постає питання про те, як відрізнити фольклорний (фольклористичний, науково-етнографічний) ансамбль від аматорського (самодіяльного) ансамблю української (народної) пісні, колективу, який часто має у своїй назві слово «фольклорний», але фактично та за змістом своєї діяльності таким не $\epsilon$. Продемонструємо це за кількома основними аспектами творчої діяльності цих колективів у порівняльній таблиці.

Отже, учасникам справжніх фольклорних репродукуючих ансамблів (клубів, студій) необхідно займатися збиранням фольклору й постійною самоосвітою, яка разом із читанням спеціальної літератури дасть базу для систематизації фахових фольклористичних знань. Збір фольклору допоможе зрозуміти місцеві особливості фольклорної культури певного регіону, району, села, адже фольклорні записи - це зафіксована традиція у слові, мелодії, діалектних особливостях, обрядах, особливостях побуту тощо. Спираючись на фольклорно-етнографічні експедиційні записи, можемо оволодівати пісенною традицією, створювати оригінальні сценарії, організовувати музеї традиційного побуту, видавати збірки фольклору та готувати публікації в місцевій пресі, знайомити 3 традиційною культурою дітей на заняттях 3 краєзнавства, виховуючи справжніх патріотів, отже, популяризувати та пропагувати традиційну спадщину українського народу.

5 Бенч-Шокало О. Автентичний гуртовий спів. Фольклорно-репродуктивний гуртовий спів. Український хоровий спів: Актуалізація звичаєвої традииії : навчальний посібник. Київ, 2002. С. 91-95, 214-230. Грица С. Відродження народнопісенних джерел. Трансмісія фольклорної традииї: Етномузикологічні розвидки. Київ ; Тернопіль, 2002. С. 198-205. Павленко І. Вокальні ансамблі сучасного побутування (жанрові особливості). URL: https://nz.lviv.ua/archiv/20134/25.pdf (дата звернення: 31.01.2021). 


\section{Таблиця 1}

\section{Порівняння особливостей фольклорного (фольклористичного)}

та аматорського (самодіяльного) ансамблів

\begin{tabular}{|c|c|}
\hline $\begin{array}{c}\text { Фольклорний/фольклористичний } \\
\text { ансамбль } \\
\end{array}$ & $\begin{array}{c}\text { Ансамбль народної пісні } \\
\text { (аматорський/самодіяльний) }\end{array}$ \\
\hline $\begin{array}{c}\text { Має синкретичний репертуар: учасники } \\
\text { ансамблю не лише співають, але й грають на } \\
\text { традиційних інструментах, виконують народні } \\
\text { побутові танці, показують ігри (наприклад, } \\
\text { весняні хороводні), народну драму (вертеп, } \\
\text { весілля) тощо. } \\
\end{array}$ & У репертуарі переважає пісенний жанр. \\
\hline $\begin{array}{c}\text { Вивчають і пропагують місцеву (локальну) } \\
\text { фольклорну традицію, зокрема співацьку, } \\
\text { інструментальну, танцювальну. }\end{array}$ & $\begin{array}{c}\text { Учасники ансамблю виконують матеріал } \\
\text { із збірок, використовують репертуар } \\
\text { інших колективів, не акцентуючи увагу на } \\
\text { місцевих традиціях. } \\
\end{array}$ \\
\hline $\begin{array}{c}\text { Відзначають свята народного календаря, } \\
\text { спираючись на місцеві традиції. }\end{array}$ & $\begin{array}{l}\text { Не дотримуються дат народного } \\
\text { календаря. }\end{array}$ \\
\hline $\begin{array}{c}\text { Учасники ансамблю ведуть збирацьку } \\
\text { діяльність, поповнюють фольклорний архів } \\
\text { (при відділі культури, кафедрі фольклору, } \\
\text { особистий архів керівника колективу); } \\
\text { виконують твори з власних записів, можуть } \\
\text { продемонструвати архів за вимогою. } \\
\end{array}$ & Зазвичай збирацька діяльність не ведеться. \\
\hline Співають ансамблевим співом, а не хоровим. & Спосіб співу може бути будь-яким. \\
\hline $\begin{array}{c}\text { Одягаються у стилі, наближеному до } \\
\text { етнографічних оригіналів, зберігаючи логіку } \\
\text { народного одягу. }\end{array}$ & $\begin{array}{c}\text { Костюм є зазвичай стилізованим. Головні } \\
\text { убори та прикраси (намисто тощо) часто } є \\
\text { гротескними. Такому костюму можна } \\
\text { дати таке визначення, як «фантазія на } \\
\text { тему архаїки», де порушеними } є \\
\text { кольорова гама, крій тощо } \\
\end{array}$ \\
\hline $\begin{array}{c}\text { Використовують народні інструменти } \\
\text { (скрипка, сопілка та інші народні духові } \\
\text { інструменти, цимбали, народна шумові та } \\
\text { ударні інструменти). } \\
\end{array}$ & $\begin{array}{c}\text { Інструменти народно-сценічні, зокрема } \\
\text { баян, контрабас. }\end{array}$ \\
\hline $\begin{array}{c}\text { Зазвичай усі учасники ансамблю співають, } \\
\text { танцюють і грають на інструментах. Немає } \\
\text { розподілу на вокальну, інструментальну та } \\
\text { інші групи. } \\
\end{array}$ & $\begin{array}{l}\text { Ансамбль має вокальну, інструментальну } \\
\text { та хореографічну групи (за можливості). }\end{array}$ \\
\hline $\begin{array}{c}\text { Співають із дотриманням принципів } \\
\text { традиційного виконавства: підголосок } \\
\text { виконується однім співаком. } \\
\end{array}$ & $\begin{array}{c}\text { Співають «вокальними партіями» за } \\
\text { партитурою. }\end{array}$ \\
\hline $\begin{array}{c}\text { Виконують справжній автентичний } \\
\text { хореографічний матеріал. }\end{array}$ & $\begin{array}{l}\text { Виконують хореографічні постановки, так } \\
\text { звані сценічні розводки. }\end{array}$ \\
\hline Вчать пісні «з голосу», від носіїв традиції. & $\begin{array}{c}\text { Вчать пісні інколи «по слуху», але частіше } \\
\text { по нотах і під фортепіано (баян). }\end{array}$ \\
\hline $\begin{array}{c}\text { Поведінка виконавців наближена до логіки } \\
\text { традиційної поведінки (дотримання вікових і } \\
\text { статевих обмежень, лідерство чоловіків, } \\
\text { дівоча скромність тощо). }\end{array}$ & $\begin{array}{c}\text { Логіка традиційної культури порушена: } \\
\text { чоловіки знаходяться на других ролях, } \\
\text { яскраво помітним є лідерство жінок; } \\
\text { молодших виставляють на передній план, } \\
\text { старших - більш досвідчених - на другий, } \\
\text { чого в традиційній культурі не може бути. }\end{array}$ \\
\hline
\end{tabular}


Сьогодні молодіжні репродукуючі фольклорні ансамблі - це єдина суспільно-культурна сила, власне, «фольклорний рух». Ці колективи мають яскраве власне «обличчя», яке визначається насамперед своєрідністю локальних фольклорних традицій, на основі яких працює колектив. Таким чином, однією 3 основних форм засвоєння цих анклавних традиційних зразків музичного фольклору для «вторинних» колективів є фольклорна експедиція.

Експедиційна діяльність фольклористів України базується на тезі про усне побутування фольклорної традиції. В цьому усному способі передачі традиції запрограмована мобільність художньої системи: тут живе і сприйняття, що зберігається у колективній пам'яті народу, i природність забуття, відмирання неживого, неприйняття чужого, неприйнятного. Тут суміщуються побут і пісня, обряд і його музичний супровід, драма й танок, рух, слово.

Саме під час експедицій, а саме польових досліджень, формується репертуар молодіжного фольклористичного колективу. Особливістю вирішення репертуарної проблеми є ставлення до традицій, як до коріння, яке ми збираємося пересаджувати на новий (міський) грунт. В усній експедиції важливим є осмислення та суміщення одночасно різних точок зору на пісню, зокрема пісня як конкретний факт, як твір, що має неповторний художньо-творчий потенціал, свою енергію, мудрість і водночас - межі реалізації. Інший аспект, який потрібно враховувати, - це жанрова приналежність будь-якої народної пісні, іiі побутування, роль у групі пісень цього жанру, у зв'язку з чим враховуються побутові та художні межі жанру. Третя складова частина - це народна пісня на рівні художнього стилю (де стиль є системою жанрів, що його складають), пісня як частина місцевого традиційного самобутнього унікального стилю, де внутрішня єдність має наслідком схожість різних пісень.

Методика усної передачі (усного переймання, вивчення) традиційного матеріалу в умовах фольклорної експедиції сьогодні вже $\epsilon$ достатньо опрацьованою й активно використовується фольклористами в активній практичній діяльності ${ }^{7}$. Такий спосіб $\epsilon$ характерним для багатьох напівпрофесійних (експериментальних, молодіжних) та аматорських (любительських) фольклорних ансамблів України. Однак найбільш ефективною формою експедиції, на нашу думку, є поєднання

6 Жуланова Н. Молодёжное фольклорное движение. Фольклор и молодёжь. От истоков к современности. Москва, 2000. С. 3-29.

${ }^{7}$ Єфремов Є., Пономаренко В. Дослідження локальної народнопісенної традиції як основа діяльності вторинного фольклорного ансамблю. Украйнське музикознавство : респ. між від. наук.-метод. зб. / редкол.: І. Котляревський (голова) та ін. Київ : Муз. Україна. Вип. 24. 1989. С. 3-16. 
усного методу та роботи зі звукозаписом музичного матеріалу. Звукозапис за допомогою «ковзного каналу», що $є$ елементарно простим порівняно 3 технічно складним багатомікрофонним записом ${ }^{8}$, сьогодні вбачається незамінним засобом під час використання усного методу для передачі пісенної традиції. Такий звукозапис $\epsilon$ досить ефективним для отримання інформації, за мінімальних витрат і зусиль він фактично продовжує на будь-який термін усну експедицію, дає можливість знову й знову долучатися до відтворення музичного матеріалу, вслухатися у голоси автентичних виконавців.

Таким чином, базовою, стрижневою, головною, основою характеристикою мистецької діяльності сучасних молодіжних фольклористичних формацій $\epsilon$ фольклорна експедиція, яка дає змогу, описуючи ту чи іншу локальну пісенну традицію, достатньо грунтовно описати умови побутування та різноманітні форми творів народної музики, зробити доволі детальний нотний запис (транскрипцію). Однак уява про пісенну традицію не буде повною, якщо разом 3 нотними транскрипціями й описами етнографічних даних ми не дамо характеристики місцевої виконавської манери, адже часом спосіб виконання, тембр, особливості вокальних штрихів стають компонентами, що мають безпосередній і доволі сильний вплив на пісенний «образ». До того ж, досліджуючи традиції пісенного фольклору у широкому сенсі, ми повинні розглядати не лише пісенні, але й хореографічні, інструментальні, обрядові та інші компоненти, що так чи інакше впливають на стан збереження місцевої пісенної культури й надають їй особливих характерних рис, а також, окрім власних дослідницьких спостережень, фольклористи мають обов'язково використовувати коментарі самих носіїв традиції, здійснені ними під час виконання твору.

Народні співаки надають характеру виконання великого значення: талановиті виконавці люблять пісню, ставляться до неї обережно, слідкують за тим, щоб інші співали «так, як треба», ніколи не дозволяють собі співати «як-небудь». Їх виконання завжди емоційне (вторинні виконавці часто бувають беземоційними), відрізняється внутрішньою пульсацією (що також часто $є$ відсутнім у вторинному виконавстві). Вони співають легко, яскраво, енергійно, акцентуючи увагу на тій чи іншій долі, створюючи унікальний акцентний візерунок. Безумовно, засвоєння такого широкого спектру проявів народних виконавських традицій є можливим лише у процесі практичної взаємодії учасників фольклорно-етнографічних експедицій з «колективним вчителем», а саме

${ }^{8}$ Коробов О. Аудіовізуальна фіксація традиційної музики в сучасних польових умовах (практичні рекомендації). Проблеми етномузикології. 2015. Вип. 10. С. 208-222. 
автентичним ансамблем, що $є$ знавцем локальної пісенної традиції i певного художнього стилю, самобутньої культури.

Традиційний «учитель»є настільки непростим і глибоким за змістом об’єктом, що контакт із ним вимагає грунтовної підготовки, адже він акумулює в собі духовний і практичний досвід народу, його знання, цінності й зразки життєдіяльності в контексті віри, моралі, естетики, менталітету, характеру народу, а традиція (передача) - це встановлення фактичного «панування» над «речами» $з$ боку їх попереднього власника на користь нового, у власність якого вони переходять ${ }^{9}$. Це цікаве формулювання із словника Ф. Брокгауза та I. Ефрона достатньо точно визначає принцип сприйняття традиції під час ходу фольклорних експедицій учасниками вторинних колективів: досліджуючи, вивчаючи, «занурюючись» у пісню, вони начебто набувають їх, i, головне, дають їм нове життя, перетворюючи їх на свою «власність». Таким чином, старовинна пісня перероджується у сучасну, стає для фольклористів«вторинників» близькою за духом, змістом і втіленням.

3 досвіду провідних практиків - фольклористів України - зрозуміло, що під час вивчення експедиційного матеріалу основним правилом $\epsilon$ обережне ставлення до першоджерела. Розуміючи усю відповідальність перед шедеврами народного мистецтва, експериментальні фольклористичні колективи не дозволяють собі легковажного до них ставлення. Другим, не менш важливим правилом $є$ сприйняття пісні як джерела духовної сили: якщо традиційний твір має такі якості, як яскравість, художньо-естетична досконалість, майстерне виконання, завжди виникає потреба перейняти й запам’ятати його, «пережити» в собі, як власне.

Недосконалі зразки традиції сьогодні, на жаль, зустрічаються набагато частіше, ніж у фольклористичній діяльності українських дослідників минулого століття. В такому разі потрібно «розгледіти» пісню, подумки іiі відреставрувати. Сучасному практику-фольклористу потрібно вміти бачити явні дефекти традиції. Виникає питання «обробки» не у сенсі пристосування, а у розумінні компетентної реставрації твору, який був записаний не у досконалому вигляді. В цьому разі потрібно знову й знову звертатися до першоджерела в обличчі автентичного колективу. Таким чином, можемо сформулювати третє правило фольклористично-експедиційної діяльності сучасних українських вторинних колективів: шлях засвоєння традиційної пісенної культури за нотними розшифровками (транскрипціями) тут $є$ зовсім не придатним. Лише коли чуєш і бачиш «живу» народну пісню, стає можливим опанування автентичного твору.

9 Брокгауз Ф., Ефрон И. Энциклопедический словарь. Санкт-Петербург, 1890-1907. URL: http://www.vehi.net/brokgauz (дата звернення: 31.01.2021). 
Фольклорна експедиція дає можливість не лише почути, але й передусім «побачити», відчути пісню, адже в цьому разі є візуальний контакт 3 автентиком-виконавцем, що дає можливість відчути усю глибину традиційного матеріалу, набути досвіду традиційного музичного мислення, виховати особливі механізми художнього сприйняття, відчути особливості музично-поетичної мови, а саме ії ладового строю (стійкість і нестійкість), тональності (інтуїтивний пошук і закріплення зручної для колективу висоти ладу), мелодичної лінії (як рухомого безперервного потоку), ритмічної і поетичної структури, темпу.

Звичайно, першим етапом засвоєння фольклорного матеріалу у вторинних молодіжних колективах $є$ наслідування (копіювання) манери співу народних виконавців-майстрів. Безперечно, легше копіювати, коли бачиш, як «учитель»-автентик формує звук, як промовляє слово, як «відчуває» пісню. 3 часом, накопиченням більшого об’єму аудіо-, відеозаписів носіїв традиційної пісенної культури, збільшенням досвіду творчих контактів 3 автентиками в рамках фольклорно-етнографічних експедицій, майстер-класів, спільної участі в народних святах, конкурсах, фестивалях народного мистецтва копіювання манери виконання зникає само по собі, адже надалі вмикається механізм аналізу прийомів голосоведення кожного конкретного виконавця - носія традиції. Цей базис дає можливість «вторинникам» дозволити собі імпровізувати під час виконання, «вживаючись» у зміст та жанрово-стильову сутність народних сільських пісень ${ }^{10}$ Безперечно, найкращі фольклорні колективи вирізняються серед інших високим рівнем виконавської майстерності. В їх складі об'єдналися не просто ентузіасти і не лише любителі поспілкуватися, не лише молоді дослідники-експериментатори, але й по-справжньому талановиті молоді співаки й виконавціінструменталісти. В репродукуючих колективах проводиться велика детальна систематична й наполеглива робота із засвоєння музичного матеріалу, над якістю звуковидобування, по наближенню до традиції першоджерела.

Отже, у секундарних (вторинних) фольклорних колективах усвідомлюється необхідність усного навчання традиційному співу: під час вивчення музично-фольклорних зразків віддається перевага роботі не за нотними зразками (розшифровками), а «на слух», а саме

10 Єфремов Є. Як пісні вчити? Як навчитися традиційного співу. URL: https://www.youtube.com/watch?v=u3TcsMkTOhY (дата звернення: 01.02.2021). Єфремов Є. Як створити власний співочий гурт? Як навчитися традиційного співу. URL: https://www.youtube.com/watch?v=OkGFdSKmmRU (дата звернення: 01.02.2021). 
опрацюванню аудіозразків, звукозаписів, зокрема багатоканальних ${ }^{11}$. Крім того, учасники молодіжних фольклористичних груп встановили міцні, багатолітні й по-справжньому дружні стосунки зі своїми «вчителями», що $€$ майстрами народного співу/гри на традиційних музичних інструментах. Отже, відбувається безпосереднє пряме спілкування «міста» із сільськими виконавцями.

Таким чином, можемо авторитетно стверджувати, що лише у процесі фольклорно-етнографічної роботи, яка має бути концептом (базисом, матрицею) мистецької діяльності народнопісенного фольклористичного колективу будь-якого статусу (професійного, аматорського), відбувається дієвий процес пізнання й засвоєння традиційної багатоголосої пісенної фактури та методів їі імпровізації. Така багатогранність художнього об'єкта, його структури, форми, змісту разом із загальною доступністю засвоєння захоплює, допомагає «проживати» пісню «зсередини», в найбільш наближеному до оригіналу варіанті, сприяючи об'єктивізації та етнографічній достовірності отриманих знань, умінь, понять, уявлень з усіх сторін життя українського народу, сконцентрованих у традиційній народній пісні.

\section{2. Фольклористичні колективи України та їх мистецька діяльність у контексті сучасних культурних практик}

Молодіжні фольклористичні ансамблі реалізовують свій мистецький потенціал на сцені, їх записує радіо і телебачення. Сцена, звичайно, є головною метою таких колективів, але вона диктує певні умови, адже більша частина життя молодих фольклористів проходить поза сценою. Поїздки у села, спілкування 3 народними виконавцями носіями традиційної культури, «внутрішня» вокально-репетиційна робота в колективі, мистецькі зустрічі 3 іншими молодіжними фольклористичними колективами, фестивалі, конкурси, народні свята, - усе це $є$ складовими частинами змісту діяльності молодіжних груп такого спрямування.

Фольклорний ансамбль - це ще й спосіб життя, у якому органічно поєднується міське й сільське, побутове й святкове (концертне), усне й писемне. Учасники фольклористичних формацій завжди 3 ентузіазмом використовують будь-яку можливість зустрітися 3 колегами по фольклорному руху, яку надають фольклорні свята та фестивалі, яких в Україні проводиться немало. Впевнено можна сказати, що в ансамблях

${ }^{11}$ Кабанов А. Современные фольклорные коллективы в городе. Методические рекомендации (в помощь руководителям и участникам городских молодёжных фольклорных коллективов). Москва, 1986. Коробов О. Польовий багатоканальний аудіозапис народномузичних творів в Україні: 3 практики звукооператора. Вісник Львівського університету. Серія «Мистецтвознавство». 2011. Вип. 10. С. 208-223. 
такого типу зазвичай панує творча атмосфера колективного пошуку репертуару, спрямування, способів функціонування фольклорного матеріалу, що засвоюється колективом, в умовах великого міста. Так, поступово формується своє фольклорне коло учасників ансамблів, їх родичів, друзів та знайомих. Таким чином, молодіжні фольклорні ансамблі орієнтовані на неформальне спілкування та побутову фольклористичну діяльність, а також на отримання й демонстрацію якісного художнього (вокального, виконавського) результату, в чому учасники фольклорних ансамблів часто досягають високого рівня знань $\mathrm{i}$ майстерності.

Фольклорні ансамблі не обмежуються лише сценічними формами, але дають насамперед зразки живого побутування культури, передають свій досвід новим поколінням, наповнюючи сучасне життя найбільш життєздатними елементами традиційної культури, тими жанрами фольклору, які є принципово «не концертними», тобто втрачають усю змістовність у невластивій їм ситуації ${ }^{12}$.

Зупинимось на одному важливому аспекті, що значно вплинув на мистецьку реалізацію фольклористичних колективів України в останній рік: світова пандемія та стрімкі зміни у соціокультурному просторі, спричинені карантинними обмеженнями, в реаліях яких ми живемо, мали наслідком надшвидкий розвиток різноманітних культурних практик, пов'язаних зі сферою культурного виробництва, розвитком та споживанням мистецького контенту у віртуальному середовищі. Проаналізуємо творчу діяльність сучасних українських репродукуючих фольклористичних колективів як складову частину сьогодення віртуальної мистецької креативної індустрії.

До таких колективів відносимо як професійні мистецькі установи (наприклад, Київський академічний театр українського фольклору КАТУФ «Берегиня»), які відтворюють традиційні народні пісні, танці, інструментальну музику в сценічних умовах (як різновид сучасного фольклоризму); репертуар таких колективів заснований на обробках фольклорних творів з відповідною трансформацією їх відтворення, що обумовлено переосмисленням фольклорної традиції в умовах сцени; так і експериментальні фольклорні ансамблі (вторинні фольклористичні формації), метою творчості яких є відродження та освоєння жанрів традиційного фольклору також, як і у професійних колективах, в недостеменному (неаутентичному) середовищі, але 3 прагненням до

12 Дорохова Е. Молодёжные фольклорные ансамбли в городе. Фольклор: проблемы сохранения, изучения и пропаганды : тезисы Всесоюзной научнопрактической конференции : в 2 ч. Москва, 1988. С. 45-46. Сінельніков I. Робота 3 фольклорним колективом: методи опанування традиційного музичного матеріалу. Імідж сучасного педагога [S. 1.]. 2019. No. 1 (184). P. 65-68. 
відтворення справжніх діалектних стилів фольклору 3 основою на фольклористично-етнографічну дослідницьку діяльність.

В умовах стрімкої віртуалізації світового культурно-мистецького простору діяльність українських фольклористів-«вторинників» набула нових форм і рис, адже кожний фольклористичний колектив/виконавець мав змогу вибрати власний напрям реалізації творчого потенціалу в умовах довготривалого вимушеного припинення активної мистецької діяльності.

Серед таких достатньо нових експериментальних фольклористичних форм творчості назвемо концерти-квести «у лісі» ${ }^{13}$, які в кінці літа - на початку осені 2020 року проводив під Києвом гурт «Божичі» (керівником є Ілля Фетисов), під час яких усі глядачі, маючи мапу та схематичні вказівки, як дістатися певної місцевості, самостійно добиралися до галявини у лісі, де відбувався «живий» концерт (без звукопідсилюючої апаратури) гурту «Божичі». Глядачі, хаотично сидячі на землі, знаходилися на обумовленій рекомендаціями МО3 відстані, але могли насолоджуватися «живим» співом традиційного автентичного матеріалу, який в оточенні дерев, поєднуючись зі свіжим повітрям, співом пташок та іншими природними звуками, мав на слухачів неабиякий позитивний, навіть катарсичний вплив.

Така форма мистецької самореалізації для українських фольклористів не $\epsilon$ новою: згадаймо славнозвісний хор «Гомін» і Леопольда Ященка ${ }^{14}$, які за часи боротьби за незалежність України у другій половині XX сторіччя знаходили свою мистецьку реалізацію на схилах Дніпра, галявинах у лісі, у київському Гідропарку, а в зимовий час - у підземних переходах до метрополітену у Києві. Такі вимушені несценічні умови творчості не привели до розпаду колективу, а згуртували його та об'єднали навколо хору велику спільноту справжніх патріотів, які в ті непрості часи тоталітарного пресингу та переслідувань через українську пісню, танець та відродження традиційних обрядових дій стверджували та будували незалежну Україну. Проводячи цю паралель, акцентуємо увагу на тому, що справжній, автентичний музичний матеріал та його виконання у природних умовах - це один із дієвих варіантів об'єднання суспільства навколо традиції, повернення до свого коріння, результатом чого може бути моральне та фізичне зцілення усієї нації, отже, підтримка

${ }^{13}$ Божичі: Ой щось чорніє тай над водою (українська народна пісня на вірші T. Шевченка, відео 3 заходу «Квест «Знайди «Божичів» у лісі», 12 вересня 2020 року). URL: https://www.youtube.com/watch?fbclid=IwAR1OI2h44G_csPq H0qh7CZ53fjuP5gnv_Trmn9VFcOYrdL4yue7tfB50ZO8\&v=-d3zS1QFEL0\&feature= youtu.be (дата звернення: 30.01.2021).

14 Хор «Гомін»: перші веснянки. Великдень, 1969. URL: https://www.youtube.com/watch?v=cSSHzsU-MKU (дата звернення: 01.02.2021). 
та збереження національної самосвідомості та самоідентифікації, що є надзвичайно важливим в умовах психологічного пресингу світової пандемії.

Певною перевагою та позитивним результатом самоізоляції визначимо винахід або переосмислення фольклористичних мистецьких форм творчості у віртуальному середовищі, таких як онлайн-концерти та стримінг-трансляції етнофестивалів (що важливо, здебільшого безкоштовні), різноманітні онлайн-етнофоруми ${ }^{15}$, фольклористичні вебінари, майстер-класи в режимі zoom-конференцій, онлайн-заняття 3 традиційного співу, віртуальні школи співу ${ }^{16}$, так звані концертиквартирники ${ }^{17}$, інтернет-вистави.

Серед цих форм фольклористичної самореалізації слід окремо охарактеризувати цикл відеолекцій із музичного фольклору, відзнятий восени 2020 року учасниками культурно-мистецького проєкту громадського об'єднання «Рись» за участю провідних українських етномузикологів (Свген Сфремов, Ірина Клименко, Маргарита Скаженик, Ганна Пеліна, Галина Пшенічкина (Качор), Сергій Постольніков) ${ }^{18}$. Впевнені, що реалізація таких проєктів (понад 60 лекцій, що супроводжуються аудіо- та відеоілюстраціями, розміщені у вільному доступі на платформі Youtube) $є$ непересічною подією для всього мистецького та освітянського середовища України, адже до фахової дискусії щодо збереження й відтворення традиційної культури таким чином долучається широкий загал зацікавлених осіб (викладачі й студенти мистецьких закладів освіти, працівники обласних, районних, сільських відділів та департаментів культури, аматори-виконавці, фольклористидослідники), а не лише вузьке коло знавців-етномузикологів.

Ще одна форма творчої реалізації в умовах карантину була винайдена фольклористами Київського національного університету культури і мистецтв, а саме студентами-учасниками фольклорного ансамблю «Кралиця» (керівником є заслужений працівник культури України Іван Сінельніков). Вимушена самоізоляція мала наслідком зацікавленість наших студентів самостійним опануванням цифрових технологій, аудіо-відеозапису музичного матеріалу та подальшого його

15 Сінельніков I. Традиційний спів. Виступ на I Міжнародному онлайнетнофорумі, червень 2020 року. URL: https://www.youtube.com/watch?v=Gg19VJ9Evc (дата звернення: 01.02.2021).

16 Народні пісні 3 Марічкою Марчик. Ч. 1. Ой там на горі. URL: https://www.youtube.com/watch?v=7tEPtBATpAQ (дата звернення: 29.01.2021).

17 Анамбль «Кралиця». «Ой ішов чумак 3 Дону». Квартирник у Івана. URL: https://www.youtube.com/watch?v=oDVTH5KEs54 (дата звернення: 29.01.2021)

18 Канал культурно-мистецького проєкту «Рись» на Youtube. URL: https://www.youtube.com/channel/UCNvwFP6xVKpEQx9JUC30Rvw/videos (дата звернення: 30.01.2021). 
монтування й створення таким чином цікавого музичного та фольклорно-етнографічного контенту.

Першим таким проєктом для фольклористів КНУКіМ став відеоролик «Лови намисто!» ${ }^{19}$, у якому дівчата-краличанки передають одна одній намисто і з'являються у традиційному українському вбранні. Це студентське відео тривалістю лише 50 секунд набрало загалом понад 1,5 мільйони переглядів на Youtube, привернуло до себе безліч прихильників традиційної української культури, мало наслідком хвилю схожих флешмобів в Україні й за кордоном, учасники яких передавали один одному хустки, чоботи, крайки тощо. Вважаємо такий широкий суспільний резонанс цього мистецького проєкту безперечним успіхом фольклористів КНУКіМ.

Назвемо ще такі творчі винаходи кнукімівських фольклористів, до яких привели пошуки нових форм віртуалізації мистецького контенту:

- запис усіх вокальних партій одного музичного твору одним студентом із подальшим монтуванням багатоголосся в один відеокадр ${ }^{20}$ (маємо сказати, це доволі непростий трудомісткий процес);

- запис одного твору кількома учасниками ансамблю та зведення усіх вокальних партій (аудіо) та усіх відеозображень в один, об'єднаний певною ідеєю та змістом, відео-аудіопроєкт ${ }^{21}$ (не менш енергозатратна, довготривала та трудомістка процедура, сам процес якої вибудовувався методом спроб і помилок, адже для того, щоб усі учасники цього мистецького проєкту співали в одній тональності та темпі, «заводчику», тобто тому, хто заспівує пісню, потрібно було записати усі іiі куплети від початку до кінця, без зупинки; усі інші співаки записували свої вокальні партії, слухаючи через навушники спів «заводчика»);

- створення цілих літературно-музичних композицій - фактично віртуальних концертних виступів, записаних окремо різними виконавцями та змонтованими в цілий мистецький продукт засобами новітніх цифрових аудіо-відеотехнологій ${ }^{22}$.

19 Лови намисто! Флешмоб у вишиванках. URL: https://www.youtube.com/ watch?v=Fx9Fy2BOqrI (Дата звернення: 31.01.2021).

${ }^{20}$ Зацвів терен ще й лоза, співає Д. Сполович (пісня з с. Водяне Запорізької області, ансамбль «Кралиця»). URL: https://www.youtube.com/watch?v=rk6pLBLet8I (дата звернення: 31.01.2021).

${ }^{21}$ Колядка «Ой учора із вечора мужицька доля похорошіла». Творчий проєкт Coфiï Рубан. URL: https://www.youtube.com/watch?v=m_DjQijJkI4 (дата звернення: 30.01.2021).

22 «Вертеп», с. Ралівка, Львівщина. Творчий проєкт Божени Масляк (ансамбль «Ладоньки). URL: https://www.youtube.com/watch?v=-02yGmKIUHk (дата звернення: 30.01.2021). 
Додамо також, що спів на свіжому повітрі у природних умовах також практикувався ансамблем «Кралиця» в теплі пори 2020 року ${ }^{23}$.

Отже, ми назвали переваги поширення творчої реалізації фольклористичних колективів у віртуальному просторі, але повинні окреслити певні об'єктивні перешкоди, 3 якими стикнулися етномузикологи (та й загалом музиканти) України на різних етапах створення свого віртуального мистецького контенту. Основною проблемою стало те, що одночасний спів кількох учасників ансамблю в умовах інтернет-мережі на сучасному етапі розвитку технологій та відставання звукових сигналів $є$ неможливим ${ }^{24}$, отже, в таких умовах процес «живої» колективної творчості (одночасного співотворення) не може відбуватися. Це спонукало музикантів шукати у віртуальній реальності нові форми реалізації творчого потенціалу та одночасної популяризації традиційного мистецтва.

3 іншого боку, шлях створення музично-фольклористичного контенту у віртуальному просторі $€$ новим, отже, вільним від напрацьованих у «живому» концертному виконанні вокальних i постановочно-сценічних «штампів». Шлях постійного пошуку нових форм (у тому числі, у вебпросторі) презентації автентичного музичного контенту дасть змогу відійти від хибної сучасної тенденції створення псевдофольклорного (або «фейклорного» ${ }^{25}$ ) продукту. Створення та поширення якісного високохудожнього та змістовного фольклористичного вебконтенту (чим зараз і займаються фольклористи КНУКіМ) сприятиме систематичній пропаганді фольклору засобами масової комунікації, пожвавленню зацікавленості суспільства народною музикою, наслідком чого стане активізація фольклорної пам'яті народу i, що найважливіше, привернення до народної творчості молоді та дітей, що сприятиме неперервності трансляції традиційної спадщини українського народу від покоління до покоління.

\section{ВИСНОВКИ}

Питання про долю традиційного музичного фольклору в сучасних умовах побутування залишається одним із найбільш вагомих i популярних тем сьогоднішнього музикознавства. Життя сучасного суспільства швидко змінюється, що викликає проблему збереження

23 Кралиця. Посію я ж конопельки. URL: https://www.youtube.com/ watch?v=7oH5rox2mXY (дата звернення: 31.01.2021).

24 Бондаренко А. Дистанційна освіта музикантів-виконавців: проблеми та перспективи. Імідж сучасного педагога. 2020. № 3. С. 69-72.

25 Івановська О. Фейклор у мистецтві: модний тренд чи лагідна денаціоналізація? (відеолекція, 24 вересня 2020 року). URL: https://www.youtube.com/watch?v=mcieUGtjnJA (дата звернення: 02.02.2021). 
традиційного фольклору. Молодіжні репродукуючі колективи, на нашу думку, $є$ тією виконавською формою, котра допоможе відродити музичний фольклор, що безповоротно зникає.

Учасники молодіжних фольклорних формацій добре розуміють, що фольклор - це і $\epsilon$ саме життя, в якому $\epsilon$ місце до прагнення i досконалості з орієнтацією на вершинні зразки й майстерне виконання традиційної пісні, а також рутинна повсякденна праця з осмислення й відродження різноманітних системних зв'язків традиційної культури, де музиці надається важливе значення, але не завжди головна роль.

Фольклорні колективи по-різному вирішують завдання 3 пропагування та популяризації народного мистецтва. Одні прагнуть до «справжності» в будь-якому прояві, а саме в манері співу, хореографії, інструментарії, костюмі; інші приділяють більшу увагу автентичності у співі, загалом у творчості; треті намагаються «втулити» народні традиції в рамки естрадного мистецтва. Безумовно, усі ці напрями мають право на існування, але лише на основі грамотного підходу до вирішення професійних завдань. В регіонах України створено сотні молодіжних і дитячих фольклорних ансамблів різних спрямувань, в основі діяльності яких $€$ збереження й пропагування місцевих виконавських традицій.

Таким чином, молодіжні репродукуючі фольклорні колективи вносять значний вклад у збереження та розвиток традиційної художньої культури, адже майбутнє є неможливим без збереження минулого багатовікового досвіду. Кожний учасник такого колективу $\epsilon$ унікальним i несе знання, отримані в процесі спілкування 3 автентичними виконавцями фольклору, переймаючи їх досвід i продовжуючи рух вперед національної культури без втрат.

\section{АНОТАЦІЯ}

Стаття присвячена питанню збереження традиційного музичного фольклору в сучасних умовах побутування, що залишається однією 3 популярних тем сьогоднішнього музикознавства. На думку авторів, саме молодіжні репродукуючі колективи є тією виконавською формою, котра допоможе відродити музичний фольклор, що безповоротно зникає. Завданням наукової розвідки є аналіз процесу, методів та форм засвоєння, трансляції, трансформації та презентації традиційної культурної спадщини українського народу у мистецькій діяльності сучасних фольклористичних молодіжних формацій.

Методологія дослідження полягає у використанні загальнонаукових та музикознавчих методів, а саме практичних, аналітичних, джерелознавчих, що дало змогу проаналізувати питання окресленого кола. Наголошується на тому, що учасники молодіжних фольклорних 
колективів добре розуміють, що фольклор - це і є саме життя, у якому є місце до прагнення й досконалості з орієнтацією на вершинні зразки й майстерне виконання традиційної пісні, а також рутинна повсякденна праця з осмислення й відродження різноманітних системних зв'язків традиційної культури.

Фольклорні колективи по-різному вирішують завдання 3 пропагування та популяризації народного мистецтва. Одні прагнуть до «справжності» в будь-якому прояві, а саме в манері співу, хореографії, інструментарії, костюмі; інші приділяють більшу увагу автентичності у співі, загалом у творчості; треті намагаються «втулити» народні традиції в рамки естрадного мистецтва. Безумовно, усі ці напрями мають право на існування, але лише на основі грамотного підходу до вирішення професійних завдань.

Отже, наукова новизна дослідження полягає в обгрунтуванні різних підходів до засвоєння традиційного музичного матеріалу у різних за творчим спрямуванням «вторинних» колективах, наголошується увага на тому, що головним підгрунтям їх творчої діяльності є систематична й поглиблена науково-етнографічна фольклористично-експедиційна діяльність учасників фольклорних колективів безпосередньо у середовищі побутування й збереження фольклорних першоджерел, а саме сільському середовищі.

Окремий розділ статті присвячено аналізу нових форм i рис діяльності українських фольклористів-«вторинників», що з'явилися в умовах стрімкої віртуалізації сучасного світового культурномистецького простору, адже кожний фольклористичний колектив/виконавець мав змогу вибрати власний напрям реалізації творчого потенціалу в умовах довготривалого вимушеного припинення активної мистецької діяльності під час пандемії. Зокрема, йдеться про такі форми мистецької діяльності, як онлайн-концерти та стримінгтрансляції етнофестивалів, різноманітні онлайн-етнофоруми, фольклористичні вебінари, концерти-квести на свіжому повітрі, майстер-класи в режимі zoom-конференцій, онлайн-заняття 3 традиційного співу, віртуальні школи співу, так звані концертиквартирники, інтернет-вистави.

Отже, проаналізовано специфічні риси мистецької діяльності молодіжних репродукуючих фольклорних колективів. Доведено, що секундарні ансамблі вносять значний вклад у збереження та розвиток традиційної художньої культури, адже майбутнє є неможливим без збереження минулого багатовікового досвіду. Кожний учасник такого колективу $є$ унікальним і несе знання, отримані в процесі спілкування 3 автентичними виконавцями фольклору, переймаючи їх досвід i продовжуючи рух вперед національної культури без втрат. 


\section{SUMMARY}

Main theme of this article is saving of Ukrainian traditional folk music in the present, which is one of the most popular themes of modern musicology. According to the authors, youth folk ensembles are the performing form that can help reviving musical folklore, which continues to disappear. The main task of scientific intelligence is: to analyze process, methods and forms of learning, translations, spreading, transformation and presentation of Ukrainian traditional cultural heritage in different artistic activity of modern youth folk organizations.

Research methodology consists using common scientific and musicological methods - practical, analytical and source-studying, that made possible analyzing the question of outlined circle. It is emphasized that the participants of youth folk ensembles understand that folklore is like lifestyle, in which there is a place to working on sound, skillful performing of traditional music and routine work on reviving different system communications of traditional culture.

Each folk group promotes and popularizes national arts differently. Some of them aim authenticity in any detail - manner of singing, choreography etc. Others are paying attention to the authenticity of the sound. Also, there are those performers, who try to mix pop and folklore manner of singing. Certainly, all these methods have the right to a life, but only on the basis of a competent approach. So, the scientific novelty of the research is in reasoning various learning methods of tradition folk music in different "secondaryperforming" folk ensembles. The basis of their's creative activities participants' folklore-expeditional activities directly in the countryside.

There is separate section of the article that is dedicated to analyzing of new ways and features of Ukrainian ethnomusicologists' activities that appeared according to rapid virtualization of world cultural and artistic space. In view of these circumstances every folk ensemble could choose the way of realization of their creativity during forced discontinuation of creative activities. In addition, the article tells about different forms of creative activities, like online-ethnic forums, folk-webinars, master classes in online mode etc.

Conclusions: analyzed specific sides of youth folk ensembles' art activities. It is proved that secondary ensembles make a significant contribution to the preservation and development of traditional art culture, because the future is impossible without preserving the past centuries of experience. Every participant of this group is unique and has knowledge that was gained during communication with authentic folk performers, learning their experience and continuing the tradition. 


\section{ЛIТЕРАТУРА}

1. «Вертеп», с. Ралівка, Львівщина. Творчий проєкт Божени Масляк (ансамбль «Ладоньки»). URL: https://www.youtube.com/ watch?v=-02yGmKIUHk (дата звернення: 30.01.2021).

2. Анамбль «Кралиця». «Ой ішов чумак з Дону». Квартирник у Івана. URL: https://www.youtube.com/watch? $\mathrm{v}=\mathrm{oDVTH} 5 \mathrm{KEs54}$ (дата звернення: 29.01.2021).

3. Андреева Е Фольклорное движение как культурный феномен второй половины XX столетия. История и современность. 2013. Вып. 2 (18). URL: https://www.socionauki.ru/journal/articles/159684 (дата звернення: 02.02.2021).

4. Бенч-Шокало О. Автентичний гуртовий спів. Фольклорнорепродуктивний гуртовий спів. Украйнський хоровий спів: Актуалізація звичаєвої традиції : навчальний посібник. Київ, 2002. С. 91-95, 214-230.

5. Божичі: Ой щось чорніє тай над водою (українська народна пісня на вірші Т. Шевченка, відео з заходу «Квест «Знайди «Божичів» у лісі», 12 вересня 2020 року). URL: https://www.youtube.com/watch?fbclid= IwAR1OI2h44G_csPqH0qh7CZ53fjuP5gnv_Trmn9VFcOYrdL4yue7tfB50 ZO8\&v=-d3zS1QFEL0\&feature=youtu.be (дата звернення: 30.01.2021).

6. Бондаренко А. Дистанційна освіта музикантів-виконавців: проблеми та перспективи. Імідж сучасного педагога. 2020. № 3. С. 69-72.

7. Грица С. Відродження народнопісенних джерел. Трансмісія фольклорної традииї: Етномузикологічні розвидки. Київ ; Тернопіль, 2002. C. 198-205.

8. Дорохова E. Молодежные фольклорные ансамбли в городе. Фольклор: проблемы сохранения, изучения и пропаганды : тезисы Всесоюзной научно-практической конференции : в 2 ч. Москва, 1988. C. $45-46$.

9. Єфремов Є., Пономаренко В. Дослідження локальної народнопісенної традиції як основа діяльності вторинного фольклорного ансамблю. Украӥнське музикознавство : Респ. між від. наук.-метод. зб. / редкол.: І. Котляревський (голова) та ін. Київ : Муз. Україна. 1989. Вип. 24. С. 3-16.

10. Єфремов Є. Як пісні вчити? Як навчитися традиційного співу. URL: https://www.youtube.com/watch?v=u3TcsMkTOhY (дата звернення: 01.02.2021).

11. Сфремов Є. Як створити власний співочий гурт? Як навчитися традиційного співу. URL: https://www.youtube.com/watch?v= OkGFdSKmmRU (дата звернення: 01.02.2021).

12. Жуланова Н. Молодёжное фольклорное движение. Фольклор $u$ молодёжь. От истоков к современности. Москва, 2000. С. 3-29. 
13. Зацвів терен ще й лоза, співає Д. Сполович (пісня з с. Водяне Запорізької області, ансамбль «Кралиця»). URL: https://www.youtube.com/watch?v=rk6pLBLet8I (дата звернення: 31.01.2021).

14. Івановська О. Фейклор у мистецтві: модний тренд чи лагідна денаціоналізація? (відеолекція, 24 вересня 2020 року). URL: https://www.youtube.com/watch?v=mcieUGtjnJA (дата звернення: 02.02.2021).

15. Кабанов А. Современные фольклорные коллективы в городе. Методические рекомендации (в помощь руководителям и участникам городских молодёжных фольклорных коллективов). Москва, 1986.

16. Канал культурно-мистецького проєкту «Рись» на Youtube. URL: https://www.youtube.com/channel/UCNvwFP6xVKpEQx9JUC30Rvw/vide os (дата звернення: 30.01.2021).

17. Колядка «Ой учора із вечора мужицька доля похорошіла». Творчий проєкт Софії Рубан. URL: https://www.youtube.com/ watch? v=m_DjQijJkI4 (дата звернення: 30.01.2021).

18. Коробов О. Аудіовізуальна фіксація традиційної музики в сучасних польових умовах (практичні рекомендації). Проблеми етномузикології. 2015. Вип. 10. С. 208-222.

19. Коробов О. Польовий багатоканальний аудіозапис народномузичних творів в Україні: 3 практики звукооператора. Вісник Львівського університету. Серія «Мистецтвознавство». 2011. Вип. 10. C. $208-223$.

20. Кралиця. Посію я ж конопельки. URL: https://www.youtube.com/ watch? $=7$ oH5rox2mXY (дата звернення: 31.012021).

21. Лови намисто! Флешмоб у вишиванках. URL: https://www.youtube.com/watch?v=Fx9Fy2BOqrI (дата звернення: 31.01.2021).

22. Народні пісні з Марічкою Марчик. Ч. 1. Ой там на горі. URL: https://www.youtube.com/watch?v=7tEPtBATpAQ (дата звернення: 29.01.2021).

23. Павленко I. Вокальні ансамблі сучасного побутування (жанрові особливості). URL: https://nz.lviv.ua/archiv/2013-4/25.pdf (дата звернення: 31.01.2021).

24. Сінельніков I. Робота 3 фольклорним колективом: методи опанування традиційного музичного матеріалу. Імідж сучасного педагога [S. 1.]. 2019. No. 1 (184). P. 65-68.

25. Сінельніков I. Традиційний спів. Виступ на I Міжнародному онлайн-етнофорумі, червень 2020 року. URL: https://www.youtube.com/ watch?v=Ggl9VJ9E-vc (дата звернення: 01.02.2021). 
26. Сінельнікова В., Сінельніков I. Деякі питання засвоєння автентичної традиції співу у міському молодіжному фольклористичному колективі. Імідж сучасного педагога. 2019. № 4 (187). C. 94-99. URL: http://isp.poippo.pl.ua/article/view/168463/178248 (дата звернення: 28.01.2021).

27. Хор «Гомін»: перші веснянки. Великдень, 1969. URL: https://www.youtube.com/watch?v=cSSHzsU-MKU (дата звернення: 01.02.2021).

28. Брокгауз Ф., Ефрон И. Энциклопедический словарь. СанктПетербург, 1890-1907. URL: http://www.vehi.net/brokgauz (дата звернення: 31.01.2021).

Information about the authors:

Sinelnikova V. V.,

Candidate of Historical Sciences, Associate Professor at the Department of Musical Arts Kyiv National University of Culture and Arts 36, Ye. Konovalets str., Kyiv, Ukraine

Sinelnikov I. G., Honored Worker of Culture of Ukraine, Associate Professor at the Department of Music Arts Kyiv National University of Culture and Arts 36, Ye. Konovalets str., Kyiv, Ukraine 